\title{
The Development and Genetic Improvement of South African Goats
}

\author{
Carina Visser and Este van Marle-Köster \\ Additional information is available at the end of the chapter
}

http://dx.doi.org/10.5772/intechopen.70065

\begin{abstract}
South Africa has a thriving goat industry, consisting of fiber, meat and dairy-producing goat breeds. These animals play an important role in terms of food security, socioeconomic welfare and cultural well-being. The South African goat industry is differentiated into a formal, commercial market with niche products such as mohair, chevon and goat's cheeses versus the informal, mainly meat-producing sector serving communal and smallholder farmers. Exotic and locally improved breeds, i.e., Angora, Saanen and Boer goats mainly serve the commercial industries, whereas the unimproved veld goat populations are well adapted in the resource-poor environments. Genetic improvement has historically been limited to the commercial breeds, but poor participation in animal recording and improvement schemes have resulted in slow genetic progress, with the exception of the Angora goat. Molecular research has opened up new possibilities for genetic characterization, preservation and utilization of the unique genetic resources retained by these animals.
\end{abstract}

Keywords: animal recording, genetic parameters, indigenous breeds, molecular genetics, quantitative selection

\section{Introduction}

South Africa contributes almost $50 \%$ to the Southern African goat population [1] with approximately 5.62 million animals [2] distributed throughout nine provinces. Approximately 2 million of these animals are found in the Eastern Cape Province, almost 1 million in Limpopo Province and just over 700,000 in KwaZulu-Natal Province. The remaining provinces share the remaining 1.8 million animals. The Angora goat population of approximately 640,000 goats is the major contributor to the income generated in the formal goat sector, by supplying 
more than $50 \%$ of the global mohair clip. The commercial meat goat industry, consisting of the Boer, Savannah and the Kalahari Red breeds makes up 1.3 million goats, with commercial dairy goats being the smallest sector, with approximately 4000 registered dairy goats. The majority (approximately 63\%) of South African goats consist of unimproved indigenous veld goats in the noncommercialized agricultural sector and are kept under small-scale conditions.

\section{Goat breeds of South Africa}

In South Africa, there are seven goat breeds that are officially recognized by the Animal Improvement Act No. 62 of 1998, which includes the Angora goat for mohair production, three meat types namely the South African (SA) Boer, Kalahari Red and Savanna breeds and three dairy breeds consisting of the Saanen, Toggenburg and British Alpine. According to historical evidence, the meat breeds originate from indigenous goat breeds believed to have migrated to Southern Africa around 500 AD [3]. The Khoisan, a local tribe, moved with their herds southwards from Northern Botswana down to the Orange River from where two additional routes were used to reach the Southern and Western Cape. These goats kept by the local people were described by the Missionary J. Burrow as "handsome goats, speckled like the leopard" [4]. The indigenous goats most likely provided the genetic basis for the development of the current meat goat breeds. In contrast with the goat meat breeds, the dairy breeds have been imported from Europe and the United Kingdom. Besides these recognized goat breeds, South Africa has a large variety of indigenous or unimproved types that contribute meat, hides and milk to smallholders and subsistence farmers [5]. The majority of commercial goat farming takes place in the eastern and northern regions of South Africa where the species is well adapted to the vegetation [2].

\subsection{Angora goats}

The Angora goat was domesticated in Turkey, from where the animals were exported to Europe during the sixteenth century in an attempt to establish a rival mohair industry. The European climate was however not suited to these goats, and South Africa (a British colony at the time) presented a suitable region for Angora goat production. The first Angora goats were imported to South Africa during 1838, followed by another 3000 goats between 1856 and 1896 [6]. The Karoo and semiarid Eastern Cape region proved to be well suited to the Angora goats, and currently, the mohair industry in South Africa consists of approximately 644,000 Angora goats (www.mohair.co.za), most of which are still farmed with in the Eastern Cape.

The Angora Goat Breeders' Society was established in 1892 and is known today as the Angora Ram Breeders. The Angora goat is a relatively small, horned mohair goat with heavy and drooping ears, as shown in Figure 1. The hair and body of these goats are white, and an excess of color in the horns, hooves, ears and the skin is not allowed. An Angora goat should have a uniform fleece with regard to length and fineness, with good luster, solid style and good character, and should also be free from kemp or colored fibers [7]. 


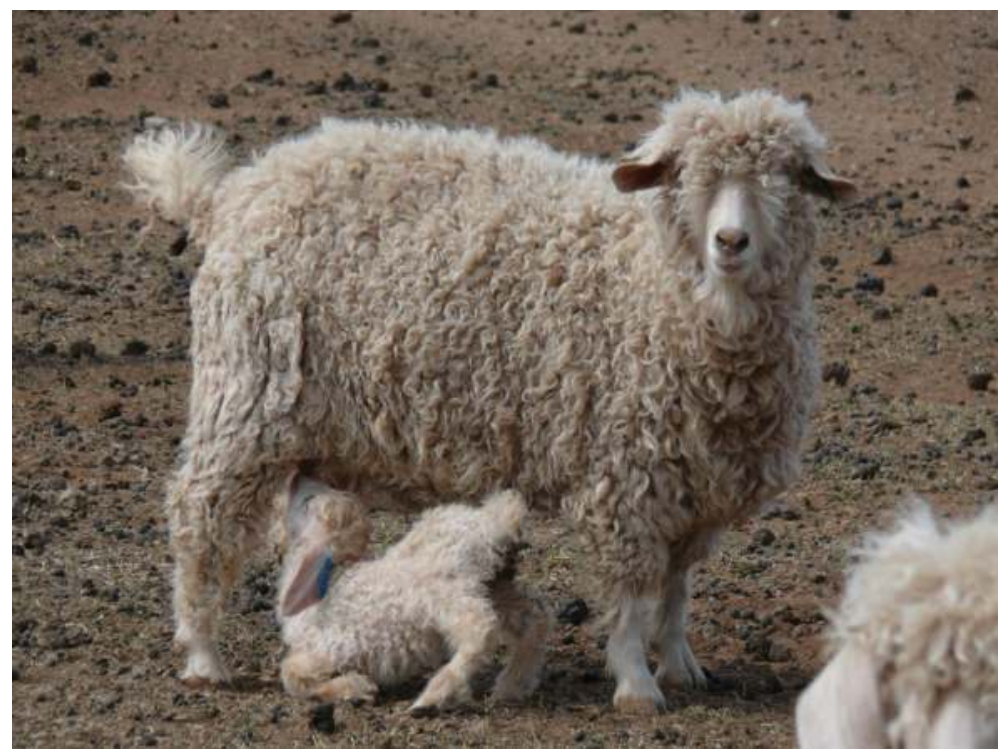

Figure 1. A typical South African Angora doe and kid (University of Pretoria).

\subsection{Meat goats}

The South African Boer goat has the oldest official history with the establishment of the South African Boer Goat Association in 1959 [4]. In the development of goat breeds during the late sixties and early seventies, the Boer goat breeders' society referred to five potential types of Boer goat in South Africa [8]. These included unimproved types such as the ordinary goat, long haired types and polled types that originated from crossbreeding with dairy breeds and native goats. The improved Boer goat was recognized as the desirable type, breed standards were formulated and a number of goat breeders commenced with directional selection and a well-defined breeding policy that resulted in the modern SA Boer goat found in commercial and other farming systems today.

This breed is characterized by the red color of the head, long ears and a white soft coat (Figure 2). A sturdy head with a compressed nose and strong horns that have a gradual backward curve are favored. The goats have fleshy, well-developed broad briskets, well-sprung ribs, broad backs and muscular legs [9]. Mature Boer goat bucks weigh between $110 \mathrm{~kg}$ and $135 \mathrm{~kg}$, and does weigh between $90 \mathrm{~kg}$ and $100 \mathrm{~kg}$ [10, 11]. The SA Boer goat does are known for their good mothering ability and can kid every 7-8 months. Some literature indicates a lower susceptibility to diseases such as blue tongue, prussic acid poisoning and, to a lesser extent, enterotoxaemia $[8,10]$.

The origin of the Kalahari Red and Savanna goat breeds is not as well documented and according to available literature probability originated from indigenous goat types [4]. These breeds have only been officially recognized in South Africa in 1990 and 1993, respectively. The 


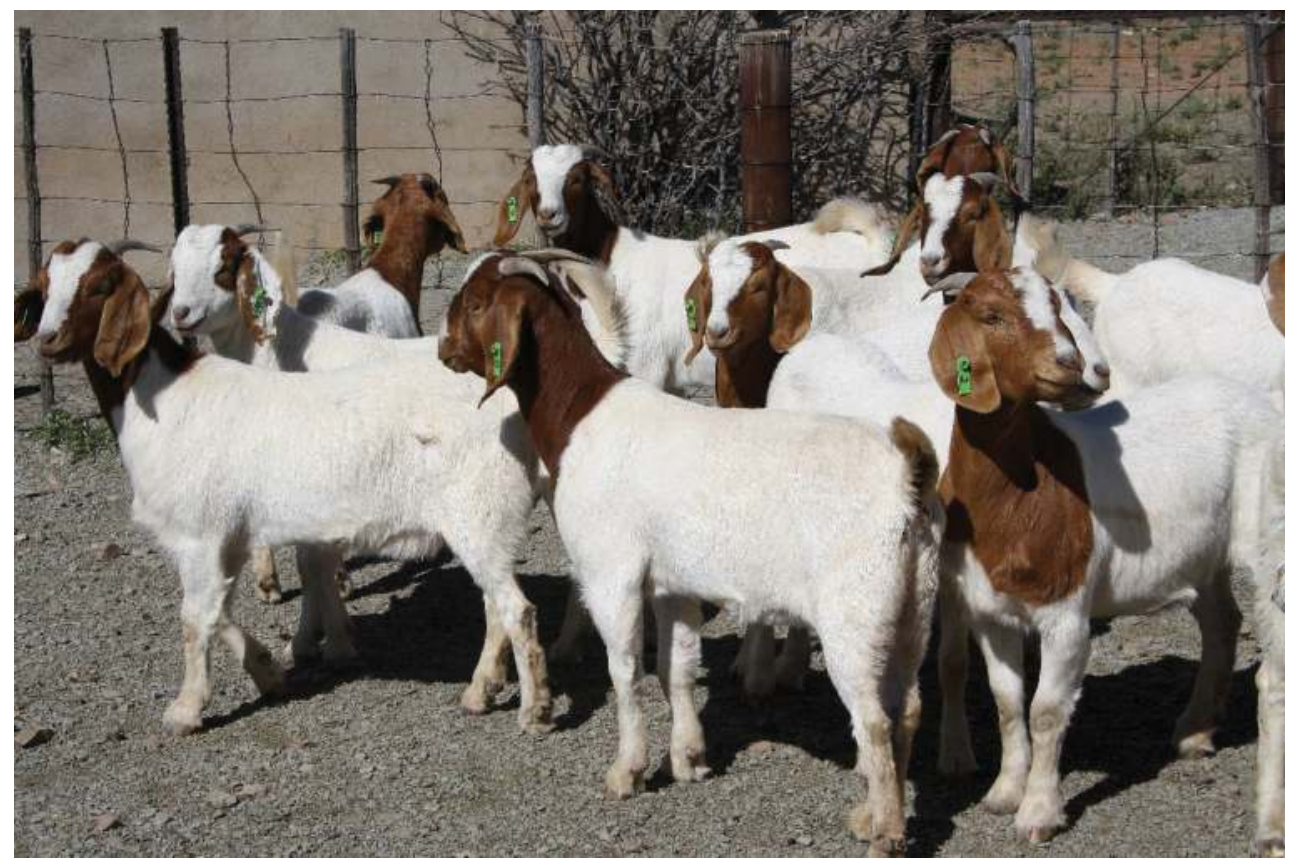

Figure 2. Typical South African Boer goats with white body and red head and neck (University of Pretoria).

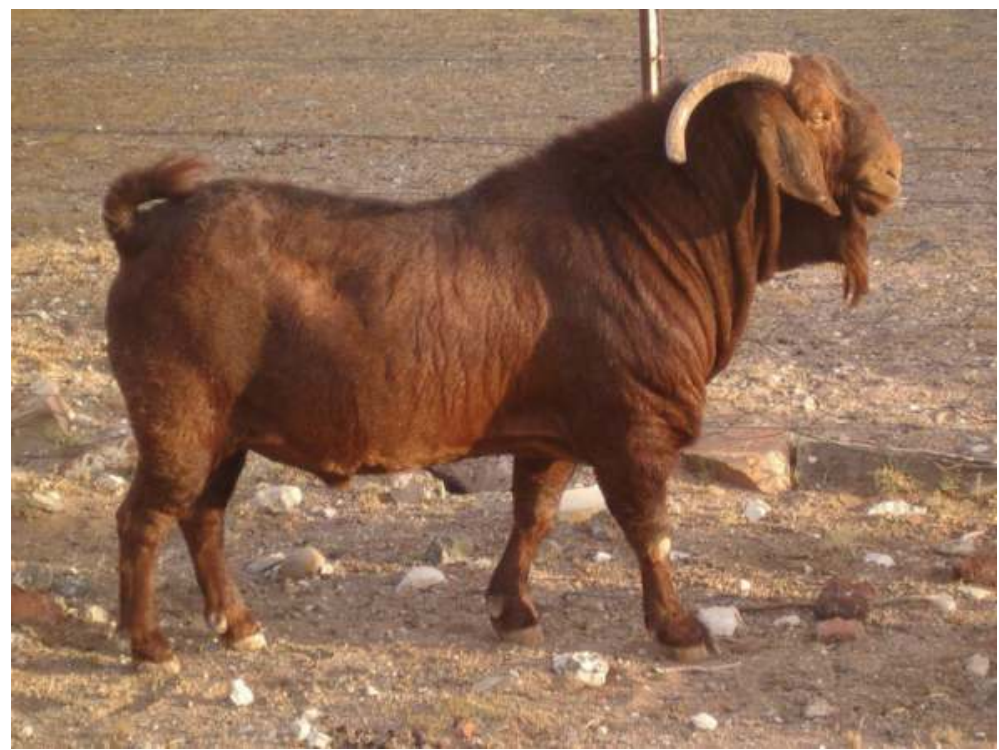

Figure 3. A Kalahari Red goat with the characteristic uniform red coat color (University of Pretoria). 
Kalahari Red has a dark red coat color and fully pigmented body that provides the advantage of high UV radiation tolerance. The Savanna goat is white in color and has short kempy hair with a black skin, horns, nose and udder [11]. These goats are also known to have well-muscled forequarters with a long neck for easy browsing. Typical Kalahari Red and Savanna goats are shown in Figures 3 and 4, respectively.

In Table 1, a summary is provided of descriptive measurements analyzed for the three commercial meat goat breeds. These breeds have been fully commercialized with official structures such as individual breed societies and well-defined breed standards. They are the main contributors to the official goat meat produced in South Africa [12] and are recognized for their superior growth and carcass traits [1].

\subsection{Indigenous veld goats and Tankwa goats}

South African indigenous goats are mostly characterized based on color variations and phenotypic characteristics such as ear length and horn shape. There is virtually no distinct breed identification, and populations are often named or identified according to the geographical region where they are kept. Various types are known, such as the Pedi, Nguni and Xhosa Lop ear ecotypes [1]. These uncharacterized veld-type goats generally have small body frames (mature females weigh approximately $40-50 \mathrm{~kg}$ ) and low carcass yields. The goats are multipurpose and are used for meat, hides and sometimes even milk for younger children, mostly in small farming systems and or for household food production.

The indigenous veld-type goats have been subjected to limited selection and are largely unimproved genotypes. They have however contributed to the development of the local meat-type goats such as the Boer goat [4] through crossbreeding. The indigenous types vary in size and

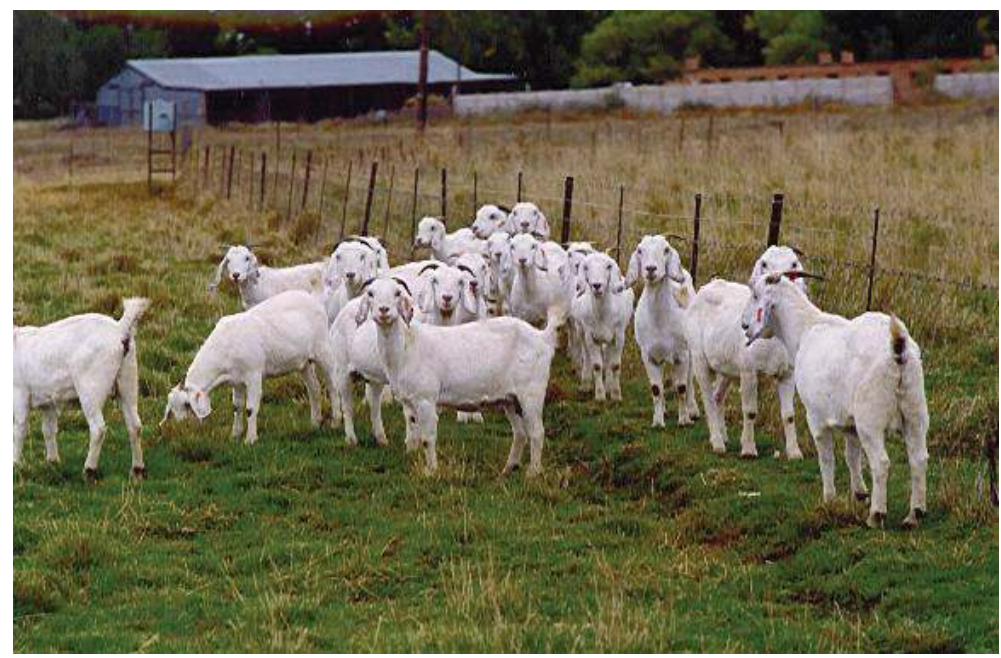

Figure 4. A herd of Savanna goats with primarily white coat color (University of Pretoria). 


\begin{tabular}{llll}
\hline & \multicolumn{3}{l}{ Body measurements in cm (least square means \pm SE) } \\
\hline & Boer goat & Kalahari Red & Savanna \\
\hline Height (H) & $56.5 \mathrm{a} \pm 0.5$ & $54.1 \mathrm{a} \pm 0.5$ & $55.7 \mathrm{a} \pm 0.5$ \\
Length (L) & $68.2 \mathrm{ab} \pm 0.8$ & $69.8 \mathrm{a} \pm 0.8$ & $64.9 \mathrm{~b} \pm 0.7$ \\
Depth (D) & $26.4 \mathrm{ab} \pm 0.3$ & $27.1 \mathrm{a} \pm 0.3$ & $24.9 \mathrm{~b} \pm 0.3$ \\
Heart girth (HG) & $90.3 \mathrm{ab} \pm 1$ & $95.3 \mathrm{a} \pm 1$ & $86.5 \mathrm{~b} \pm 1$ \\
Hock length (HL) & $28.3 \mathrm{a} \pm 0.5$ & $27.7 \mathrm{a} \pm 0.5$ & $23.5 \mathrm{~b} \pm 0.5$ \\
Head width (HW) & $7.7 \mathrm{a} \pm 0.2$ & $6.6 \mathrm{~b} \pm 0.3$ & $5.6 \mathrm{c} \pm 0.2$ \\
Head length (HL) & $17.2 \mathrm{a} \pm 0.3$ & $15.7 \mathrm{~b} \pm 0.2$ & $15.8 \mathrm{ab} \pm 0.2$ \\
Neck circumference (N) & $48.3 \mathrm{a} \pm 4$ & $42.5 \mathrm{ab} \pm 3.8$ & $37.7 \mathrm{ab} \pm 3.7$ \\
Tail length (TL) & $12.2 \mathrm{ab} \pm 0.3$ & $13.2 \mathrm{a} \pm 0.3$ & $13.3 \mathrm{a} \pm 03$ \\
Pelvic width (PW) & $13.8 \mathrm{a} \pm 0.3$ & $11.1 \mathrm{~b} \pm 0.3$ & $11.4 \mathrm{~b} \pm 0.3$ \\
Pelvic length (PL) & $19.7 \mathrm{a} \pm 0.4$ & $20.5 \mathrm{a} \pm 0.3$ & $19.1 \mathrm{a} \pm 0.3$ \\
Ear length (EL) & $21.4 \mathrm{a} \pm 0.3$ & $19.2 \mathrm{~b} \pm 0.2$ & $19.5 \mathrm{~b} \pm 0.2$ \\
\hline
\end{tabular}

Table 1. Description of body measurements $(\mathrm{cm})$ recorded for Boer goats, Kalahari Red and Savanna goats (adapted from Ref. [11]).

are often promoted as having special adaptive characteristics, including a higher tolerance for tick-borne diseases compared to the commercial goat breeds $[8,10]$. In Figure 5, a typical South African veld goat is shown.



Figure 5. A herd of South African unimproved veld goats (Rauri Alcock). 
The Tankwa goat refers to a population of feral goats that are found in the Northern Cape. Although they have been known to roam the Tankwa National Park for at least 80 years, they have only been identified and studied as a distinct population over the past decade. Their current population size is estimated at approximately 200 goats [1]. These goats have survived and reproduced in one of the harshest climatic regions of South Africa with regard to temperature and vegetation and hold potential for their unique adaptive traits.

\subsection{Dairy goats}

Dairy goats were introduced to South Africa at the turn of the twentieth century, originating primarily from Switzerland and the United Kingdom. The SA Mich Goat Breeders' Society was formed in 1958 but formal milk recording for dairy goats only started in the 1981/82 production year as the number of lactation records was low and variable before then [13]. Originally four breeds were officially recognized in South Africa, namely the Saanen, Toggenburg, British Alpine and an Anglo-Nubian Swiss composite [29]. Currently, the milk goat breeds include Saanen, Toggenburg and British Alpine breeds and crosses between these breeds are often used in commercial milk goat production systems [29]. The Saanen breed was the first milk goat breed to be imported to South Africa in 1898 [13] and is known for its high milk yield. The Toggenburg and British Alpine were imported during the early 1900s. These two breeds with dark pigmentation are favored for their adaptability to the climatic challenges of South Africa that includes high average temperatures and UV intensity. The Toggenburg furthermore also produces milk with a higher butterfat compared to the Saanen [13], which is important for production of cheese.

\section{Quantitative selection and genetic improvement}

Genetic improvement of small stock in South Africa can largely be attributed to the research performed over many decades in official research and prestige flocks. The results from the research flocks set the trends for selection and breeding programs, while the prestige flocks confirmed the value of applying a scientific approach to the farming community [14]. Performance recording was introduced for small stock, including goats, as early as 1956 by the Department of Agricultural and Technical services. Since then, production systems and environments have evolved and new selection tools became available for additional measurements, e.g., for fiber traits [15]. Advancements in the statistical methodologies for genetic evaluations made estimated breeding value possible for the breeds where sufficient animal and pedigree recording has been performed [14].

The genetic improvement of goats has been slow and less spectacular compared to sheep and other livestock species in South Africa. Of the goat breeds, most of the genetic improvement took place in the Angora goat due to the high economic value of mohair and South Africa being one of the largest producers of mohair in the world [16]. The poor participation in the National Small Stock Improvement Scheme (NSIS) by the meat and dairy goat breeders limits the potential genetic improvement, as limited phenotypic and pedigree recording occurs. Several factors play a role in the relative poor participation of SA goat breeders in animal 
recording, including difficulties in recording on large extensive farming units, multi-sire practices presenting challenges for accurate parentage verifications and the cost of using modern technology for measuring traits of economic importance. Beef remains the primary choice for meat consumption by the consumer, and goats have often been neglected in the creation of new markets and products. All these factors may play a role in decision making by farmers when it comes to the costs involved in official animal recording and genetic evaluations. Furthermore, the unimproved veld goat is largely uncharacterized and has not been subjected to artificial selection or improvement strategies. It presents opportunities to utilize these goat types for improvement of the broader goat population due to their unique adaptive traits, but at the same time poses a danger if the selection strategies are not well formulated and implemented. Care must be taken that the uniqueness of genetic resources is conserved while implementing genetic progress.

\subsection{Angora goats}

The most significant genetic improvement in the South African Angora goat population took place over the past four decades. Although the National Small Stock Information Scheme was established in the 1950s, the uptake by Angora goat breeders was slow. A pilot study for animal recording in Angora goats was only implemented in 1983 [17]. The participation of Angora breeders in this scheme was voluntary and has remained poor over the past few decades. A lack of complete data for South African Angora breeders [18], combined with challenges regarding parentage verification, currently limits the application of breeding values.

In 1988, a research flock was established with the aim of breeding fine-hair producing Angora goats, without sacrificing body weight $[14,19]$. Selection indices were made available to the breeders with emphasis on fiber diameter, fleece weight and body weight in varying ratios $[20,21]$. This selection strategy resulted in a significant improvement of the fiber diameter and the general fitness of the Angora goat population [19].

The development of Optical Fiber Diameter Analyzer (OFDA) technology was important for obtaining accurate measurements for the full fiber profile. It has been implemented since 1992 in routine fleece measurement in South Africa by a number of breeders [22]. The quality traits associated with the full diameter profile (including coefficient of variation of fiber diameter, comfort factor and spinning fineness) hold potential for inclusion in the breeds' selection indices. In Table 2, a summary is provided of available heritability estimates for fiber quality traits in SA Angora goats [15].

Unfavorable genetic correlations between fiber diameter and fleece weight remain a challenge [22], and higher participation in recording and genetic evaluations will be required for further genetic improvement.

\subsection{Meat goats}

Most of the available research on meat goats was performed on the SA Boer goat, focusing on phenotypic characteristics [10] and production traits [8, 10]. Average reproductive performances for the Boer goat are reported [10] based on records obtained over a 20-year period, included a kidding rate (kids born/does mated) of $189 \%$, fecundity of $210 \%$ and a weaning rate 


\begin{tabular}{ll}
\hline Trait & $h^{2}$ \\
\hline Fleece weight $(\mathrm{kg})$ & $0.19 \pm 0.04-0.24 \pm 0.03^{*}$ \\
Fiber diameter $(\mu \mathrm{m})$ & $0.26 \pm 0.05-0.45 \pm 0.03^{*}$ \\
Coefficient of variation of fiber diameter $(\mu \mathrm{m})$ & $0.37 \pm 0.10^{* *}$ \\
Standard deviation of fiber diameter & $0.32 \pm 0.11^{* *}$ \\
Comfort factor $(\%)$ & $0.63 \pm 0.11^{* *}$ \\
Spinning effective fineness & $0.61 \pm 0.10^{* *}$ \\
$\begin{array}{l}\text { Standard deviation of fiber diameter along the length of } \\
\text { the staple }(\mu \mathrm{m})\end{array}$ & $0.14 \pm 0.08^{* *}$ \\
\hline
\end{tabular}

* Snyman and Olivier [21, 24]; Visser et al. [22].

${ }^{* *}$ Visser et al. [22].

Table 2. Heritability estimated for fiber quality traits in SA Angora goats obtained from OFDA measurements.

of $149 \%$ with a weaning weight of $29 \mathrm{~kg}$ at 120 days. The SA Boer goat has also been found to be early maturing with a high incidence of multiple births. Approximately $56.5 \%$ twins, $33.2 \%$ triplets and $2.4 \%$ quadruplets born were reported in a study on the influence of age on the reproductive performance of the improved Boer goat [8]. The high fecundity poses some obvious advantage under optimal feeding conditions, but could also result in increased kid mortality when reared under extensive conditions, especially with kids born as triplets and quadruplets. Some genetic progress is evident in growth traits as can be seen in the increase in 100-day weights based on performance of tested goats corrected for age and birth status from 1998 (25.3 kg for males to $22.3 \mathrm{~kg}$ for females) to 1996 (26.9 $\mathrm{kg}$ for males and $23.4 \mathrm{~kg}$ for females) [8].

Despite the availability of animal recording for small stock, the participation remains poor with only $38 \%$ registered Boer goat, $41 \%$ Kalahari Red and $67 \%$ Savanna goat breeders taking part in the Logix recording system for small stock [24]. Only one indigenous goat veld goat breeder takes part in recording out of 14 registered breeders. Figure 6 highlights the poor participation of meat goat breeders in the NSIS.

The poor participation in animal recording of meat goats limits the potential for estimation of genetic parameters for traits of economic importance. In Table 3, available heritability estimates are presented for reproductive and growth traits. The available records for postweaning weights in South African Boer goat were insufficient for estimation of heritability [13]. A heritability value of 0.45 was reported for yearling weights in Australian Boer goats [25].

Selection progress for preweaning weights is likely to be slow due to low heritability estimates, whereas postweaning growth tends to exhibit higher heritability as seen in most farm animal species. The challenge for genetic improvement in the SA meat goat breeds lies in obtaining more and accurate recording for larger numbers of registered animals. This will enable genetic evaluations for breeding value estimation that can be applied by individual goat breeders in their herds as well as improvement of the national flock. A number of studies have highlighted the meat characteristics of South African Boer goat [28], but no genetic parameters are available for selection for improved carcass traits. 


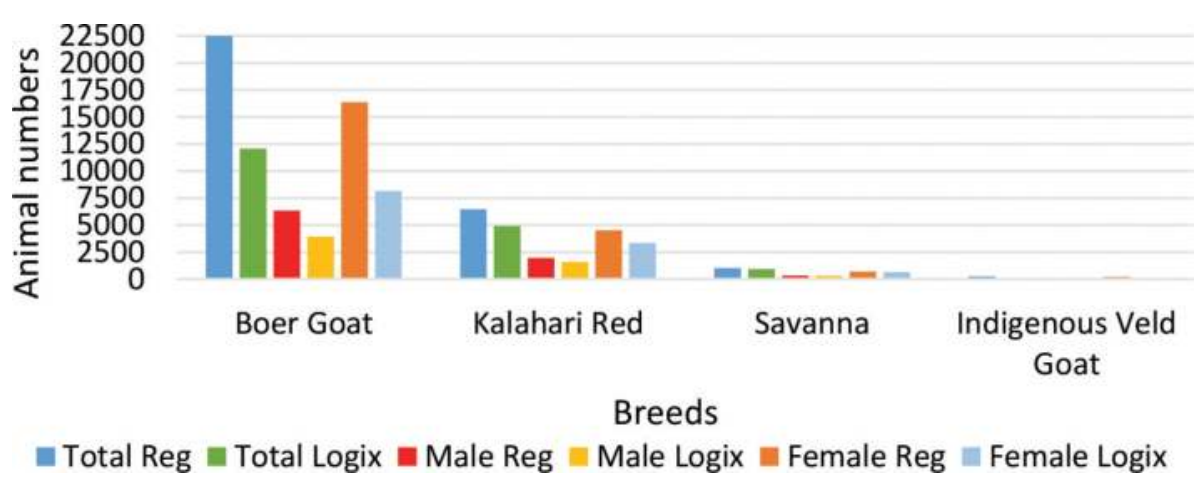

Figure 6. Participation of meat goat breeders in the National Small Stock Improvement Scheme [24].

\begin{tabular}{lll}
\hline Trait & $h^{2}$ & References \\
\hline Birth weight & $0.05-0.14$ & Schoeman et al.[26] \\
Weaning weight direct & $0.18-0.15$ & $\begin{array}{l}\text { Van Niekerk et al. [26]; Schoeman } \\
\text { et al. [27] }\end{array}$ \\
Weaning weight maternal & $0.05-0.45$ & $\begin{array}{l}\text { Van Niekerk et al. [26]; Schoeman } \\
\text { et al. [27] }\end{array}$ \\
ADG & 0.170 & Schoeman et al. [26] \\
\hline
\end{tabular}

Table 3. Heritability estimates for preweaning weights of Boer goats.

\subsection{Dairy goats}

The South African dairy population is small in comparison with the other goat breeds and small stock. There are currently 45 registered herds representing 16,561 animals [24], and the remaining animals are used in commercial milk operations. Of the 45 herds, 16 herds (approximately 1217 goats) participate in official recording. Although participation in official animal recording is limited, the opportunity is available to record milk yield, milk composition and linear traits for selection and improvement. Heritability estimates have been reported for the SA Saanen for milk yield (0.23), butter fat yield (0.22) and protein yield (0.20). Protein and butterfat percentages had a heritability of 0.44 and 0.21 , respectively [29].

Despite this relatively small population size, a niche market is served with the production of fresh milk and specialty cheeses. Marketing of these products occurs mostly in an informal way, such as by selling directly to consumers via on-farm sales, or at various markets. The renewed interest in organic products and dairy goats in general may result in breeders adopting modern technologies to overcome limitations in parentage recording and thus improved recording in order to perform accurate selection for long-term genetic improvement. 


\section{Molecular research and genetic improvement}

Since the advent of molecular genetics, research on goats has entered a new era, also influencing the South African goat populations. The first research on South African goats was performed using microsatellite markers in the early 2000s and mainly involved genetic diversity and characterization studies. Genetic characterization assists in the conservation of unique characteristics of indigenous populations, whereas genetic diversity has a direct influence on genetic progress, selection strategies and the control of inbreeding levels. The identification of quantitative trait loci (QTL) explaining significant fractions of the genetic variance in economically important traits could lead to increased accuracy of estimated breeding values (EBVs) with a corresponding faster rate of genetic improvement. A few QTL identification studies were performed on Angora goats, but the limited amount of variation explained by these fragments restricted the application of the results in terms of marker-assisted selection (MAS). Some effort has gone into sequencing genes of economic importance and estimating their population frequencies as well as identifying novel variants in the local populations. The first caprine single nucleotide polymorphism (SNP) chip became commercially available in 2012, and since then (as with almost all other livestock species) SNP markers have become the marker of choice.

\subsection{Angora goats}

Without a doubt, the Angora goat breed is the South African goat breed on which most molecular research has been performed. The SA Angora goat served as the model breed for improving the goat linkage map in 2010, using 94 microsatellite markers [30]. Both the accuracy and the coverage of the map were improved by adding markers, correcting previously reported order alignments and decreasing map distances. This linkage map formed the basis for a number of studies performed on the SA Angora goat.

Angora goats in South Africa are primarily farmed extensively and are subjected to group mating and over-mating. This limits accurate parentage recording and has a negative effect on the accuracy of estimated breeding value estimation and selection progress. A DNA parentage verification panel was created, using 14 microsatellite markers with a combined probability of exclusion of $99.7 \%$ [31]. The impact of DNA-based parentage verification on EBV accuracies and ranking of sires were evaluated a few years later [32]. It was shown that correct allocation of parentage had a significant effect on EBV estimation and ranking of sires, especially for growth traits. DNA-based parentage verification enhanced selection accuracy and would result in faster genetic progress.

Phenotypic recording and EBV selection on mohair and growth traits were relatively successful during the 1980-1990s. However, intense selection pressure for increased mohair quality and yield resulted in small, unthrifty goats with high mortality rates. QTL identification studies were performed to identify chromosomal segments associated with product and quality traits of mohair [33] as well as preweaning growth [34]. Eighteen QTL for mohair traits (including fleece weight, fiber diameter, coefficient of variation of fiber diameter, comfort factor, spinning fineness and variation along the length of the fiber) were identified on 13 chromosomes [15]. In the study focusing on preweaning growth traits, four chromosomal regions of interest with an influence on birth weight were identified on $\mathrm{CHI} 4,8,18$ and 27 
and two candidate regions for weaning weight on CHI 16 and 19, respectively [34]. Although putative QTL were identified in both studies, the QTL explained limited phenotypic variation of the traits, which is one of the main restrictions of marker-assisted selection. No MAS has yet been implemented in the SA Angora goat breed.

The QTL identification study did however indicate that QTL associated with mohair production and quality were located on chromosomes where the KRT and KAP genes have previously been assigned to mainly CHI 1 and 5 [33]. Polymerase chain reaction (PCR) and sequencing technology were used to identify and characterize KAP 1.1, KAP 8.1 and KAP 13.3 in South African Angora, Boer and Angora x Boer goat populations. A total of 19 novel variants were identified in total, and in these, three genes were responsible for structure and quality of hair fibers. The predominant alleles differed between the various populations and together with high levels of observed heterozygosity hold promise for selection based on favorable allelic associations [35].

The development of a moderate-density genotyping tool, the 50K SNP chip (Illumina Inc., San Diego, CA) [36], was a key milestone for molecular research in goats. Due to the fact that no fiber-producing breeds were included in the development of this commercial chip, it was first validated in the SA Angora goat population [37]. Fortunately, the high level of polymorphism observed ( $88.1 \%$ of loci) and the sufficient observed heterozygosity levels in the population (0.365) made the bead chip suitable for application in this breed.

The 50K SNP chip was subsequently used to estimate genetic diversity in the SA Angora goat. Results indicated that sufficient genetic diversity still exists within this breed to allow successful selection strategies and genetic improvement [38]. A high proportion of SNP with low minor allele frequency (MAF) values suggested a high proportion of fixed alleles, which was in line with the high selection pressure on specific traits within this population. An linkage disequilibrium (LD) estimate (using the $r^{2}$ measure) of 0.15 was calculated, which implied that a denser SNP genotyping array would be necessary before genomic selection (GS) could be considered for the SA Angora.

The SA Angora goat was included in a study to analyze the genetic variability of Angora goats from three distinct geographical locations (South Africa, France and Argentina) in order to assess the influence of genetic and geographical isolation [39]. The fixation index (FST) indicated three distinct subpopulations, with intrapopulation values $(0.12)$ corresponding to those normally observed between breeds. An effective population size (Ne) of 93 was estimated for the SA Angora goat, 100 generations ago, and is currently probably even lower. The distinctiveness of the South African population indicated strict directional selection which has resulted in a well-defined cluster. The high diversity between populations could be useful when exchanging genetic material to improve certain unfavorable characteristics of specific populations.

\subsection{Commercial and indigenous meat goats}

Both commercial and indigenous goats have been included in studies where DNA markers have been applied to gain insight into their genetic diversity and population structure. However, significantly, less research in terms of molecular studies has been performed on meat goats than on the Angora goat breed. 
The first molecular study on SA meat goats was performed in 2004 when the genetic variation of the three commercial breeds as well as three indigenous goat populations were investigated using microsatellite markers [40]. A clear differentiation between the Kalahari Red and Boer goat breeds was observed, whereas the Savanna breed showed significant genetic similarity to the Boer goat. Limited differentiation was observed between the veld goat populations, as was expected. Of all the breeds and populations, the Kalahari Red breed was the most clearly differentiated on a genetic level. The distinctiveness of the Kalahari Red breed was further investigated [41], also using microsatellite markers. Although it appeared that the breed was largely uniform, limited differences suggested local selection and adaptation. The clear genetic differentiation of the Kalahari Red breed was confirmed by a later study focusing on only commercial goat breeds [11]. A factorial correspondence analysis was performed with microsatellite data and the Kalahari Red goats clustered on their own, while the Boer goat and Savanna populations tended to overlap.

The commercial Boer goat and Kalahari Red breeds, as well the Tankwa and two indigenous populations, were included in a study to characterize African goat populations using the Illumina Goat SNP50K genotyping array [42]. These South African breeds showed a higher level of variation when compared to other African populations. Preliminary results were reported by $[43,44]$ on the population structure and landscape genomics of indigenous goats using genome-wide SNP data. The goat populations showed sufficient genetic diversity, and the Tankwa population was revealed as a distinct breed. Associations between the genomic variation of the goats and climatic conditions were limited to associations with longitude, temperature and altitude using the spatial analyses method.

The genetic architecture of the three commercial meat breeds, the Tankwa and five distinct ecotypes (Nguni, Venda, Xhosa, Zulu and Tswana) were investigated by Ref. [45]. Ecotypes were found to have the highest levels of genetic diversity and low levels of inbreeding, probably due to the lack of directional selection in communal systems. Most of the ecotypes showed some level of genetic relatedness with one another. The Tankwa breed was again identified as a unique genetic resource with low genetic diversity and high inbreeding levels, which can be attributed to the small population size and geographical isolation of these animals.

\subsection{Dairy goats}

The Saanen, British Alpine and Toggenburg are the three breeds contributing to South Africa's small dairy goat industry. Most goat milk is processed and sold as goat's cheese; thus, the quality of the milk produced and specifically the casein content is of importance. Limited molecular research has been performed on these breeds.

To date, two studies have been performed to characterize casein in the SA goat breeds, one on $\kappa$-casein [46] and another on $\alpha \mathrm{S} 2$-casein [47]. The first study investigated indigenous, Boer and Saanen goats using restriction fragment length polymorphism (RFLP) and DNA sequencing. Two less favorable alleles ( $\mathrm{B}^{\prime}$ and $\mathrm{H}$ ) were found exclusively in the meat goat populations, while the favorable B allele was fixated in the Saanen goats. In the latter study, $\alpha$ S2-casein was genotyped in the three SA dairy breeds, as well as in some meattype goats using DNA sequencing. Four alleles and 10 genotypes were observed across the 
populations, with the A allele being the most frequent in all the breeds. Limited gene-specific selection opportunities are possible based on these results.

The genetic diversity of SA dairy goats was investigated using a panel of 25 microsatellite markers [48]. High levels of diversity were estimated in all three breeds, with heterozygosity values exceeding $60 \%$. Limited inbreeding was observed within the populations. The genetic differentiation between the dairy breeds was very low, as could be expected within one production type. An admixture group of animals was identified, suggesting that inadvertent crossbreeding between purebred animals was taking place. The SA Milch Goat Breeders' Society allows the registration of goats with unknown pedigree, based on a physical inspection (mainly color pattern and functional efficiency). It has however been clearly demonstrated that coat color is not a definitive way of assigning breed status. Some dairy goats were included in the SNPbased genetic diversity study by Ref. [38]. The results corresponded with that of the previous study, with relatively high gene diversity estimates within the breeds. A $30 \%$ co-ancestry was calculated between the breeds, supporting the previous findings [48] regarding admixture.

\section{Conclusion}

The various goat breeds and populations in South Africa serve a number of purposes ranging from important economic contributions to the commercial livestock production sector, to the improvement of livelihoods and food security in rural communities. Genetic progress can primarily be attributed selection following a quantitative approach, with a focus on fertility, growth and some breed-specific production traits such as fiber yield. Future research and selection for genetic improvement will most likely be targeted toward molecular-based approaches. Molecular research has shown that most SA goat breeds have sufficient genetic diversity to be exploited in selection programs. Specific projects are targeted toward the identification of genes associated with traits of economic importance, managing inbreeding levels and sustainable conservation and utilization of scarce genotypes.

\section{Author details}

Carina Visser* and Este van Marle-Köster

*Address all correspondence to: carina.visser@up.ac.za

Department of Animal and Wildlife Sciences, University of Pretoria, South Africa

\section{References}

[1] Mohlatlole RP, Dzomba EF, Muchadeyi FC. Addressing production challenges in goat production systems of South Africa: The genomics approach. Small Ruminant Research. 2015;131:43-49 
[2] DAFF. National Livestock Statistics. Newsletter. Directorate: Statistics and Economic Analysis, Pretoria, South Africa; 2016

[3] Maree C, Plug I. Origin of Southern African livestock and their potential role in the industry. In: Casey M, editor. Livestock Production Systems. Pretoria, South Africa: Agricultural Development Foundation; 1993. p. 10-11. ISBN: 0-620-17126

[4] Campbell QP. The origin and description of Southern Africa's indigenous goats. South African Journal of Animal Science. 2003;4:18-22

[5] Mahanjana AM, Cronje PB. Factors affecting goat production in a communal farming system in the Eastern Cape region of South Africa. South African Journal of Animal Science. 2000;30:149-154

[6] Friedrich H. Evaluation of microsatellite markers for parentage verification in South African Angora goats [thesis]. Pretoria: University of Pretoria; 2009

[7] Snyman MA. South African goat breeds: Angora goat. Info-pack Ref. 2014/001. Grootfontein Agricultural Development Institute; 2014 Available from: http://gadi.agric. za/InfoPacks/infopacks.php [Accessed 2017-06-26]

[8] Erasmus JA. Adaptation to various environments and resistance to disease of the improved Boer goat. Small Ruminant Research. 2000;36:179-187

[9] Sambraus HH. Goats. In: Sambraus HH, editor. A Colour Atlas of Livestock Breeds. Germany: H.H. Wolfe Publishing; 1992. pp. 137-156

[10] Malan SW. The improved Boer goat. Small Ruminant Research. 2000;36:165-170

[11] Pieters A, van Marle-Köster E, Visser C, Kotze A. South African developed meat type goats: A forgotten animal genetic resource? Animal Genetic Resources Information. 2009;44:33-43

[12] Simela L, Merkel R. The contribution of chevon from Africa to global meat production. Meat Science. 2008;80:101-109

[13] Olivier JJ, Cloete SWP, Schoeman SJ, Muller CJC. Performance testing and recording in meat and dairy goats. Small Ruminant Research. 2005;60:83-93

[14] Schoeman SJ, Cloete SWP, Olivier JJ. Returns on investment in sheep and goat breeding in South Africa. Livestock Science. 2010;130:70-82

[15] Visser C, van Marle-Köster E. Strategies for the genetic improvement of South African Angora goats. Small Ruminant Research. 2014;121:89-95

[16] DAFF. Trends in the Agricultural Sector. Directorate Information and Knowledge Management, Pretoria, South Africa; 2015. p. 61

[17] Delport GJ, Erasmus GJ. Breeding and improvement of Angora goats in South Africa. In: Proceedings of the 2nd World Congress on Sheep and Beef Cattle Breeding. Pretoria, South Africa, AGRIS; 1984; p. 393-398 
[18] Olivier WJ, Snyman MA. Interpretation and application of performance testing data. Grootfontein Agric. 2011;11:1

[19] Snyman MA. Evaluation of a genetically fine mohair producing herd. Small Ruminant Research. 2002;43:105-113

[20] Snyman MA, Olivier JJ, Wentzel D. Breeding plans for South African Angora goats. Angora Goat and Mohair Journal. 1996;38:23-31

[21] Snyman MA, Olivier JJ. Genetic parameters for body weight, fleece weight and fibre diameter in South African Angora goats. Livestock Production Science. 1996;47:1-6

[22] Visser C, Snyman MA, van Marle-Köster E, Bovenhuis H. Genetic parameters for physical and quality traits of mohair in South African Angora goats. Small Ruminant Research. 2009;87:27-32

[23] Snyman MA, Olivier JJ. Repeatability and heritability of objective and subjective fleece traits and body weight in South African Angora goats. Small Ruminant Research. 1999;34:103-109

[24] SA Studbook. Annual Report. 2015. pp. 14-15. Available at http://www.sastudbook. co.za/images/photos/Annual_Report_all_2015.pdf [Accessed 2017-06-26]

[25] Ball AJ, Brown DJ, Spiker SA, Field SR, Banks RB. Opportunities for genetic development of the Boer goat in Australia using Kidplan. Proceedings of the Association for the Advancement of Animal Breeding and Genetics. 2001;14:445-448

[26] Schoeman SJ, Els JF, van Niekerk MM. Variance components of early growth traits in the Boer goat. Small Ruminant Research. 1997;26:15-20

[27] van Niekerk MM, Schoeman SJ, Botha M, Casey NH. Heritability estimates for pre-weaning growth in the Adelaide Boer goat flock. South African Journal of Animal Science. 1996;26:6-10

[28] Casey NH, Webb EC. Managing goat production for meat quality. Small Ruminant Research. 2010;89:218-224

[29] Muller CJC. Genetic parameter estimation and breeding plans for the South African dairy goat herd [PhD dissertation]. Stellenbosch: Department of Animal Sciences, Faculty of Agricultural and Forestry Sciences, University of Stellenbosch; 2005

[30] Visser C, Crooijmans RP, van Marle-Köster E. A genetic linkage map for the South African Angora goat. Small Ruminant Research. 2010;93:171-179

[31] Visser C, van Marle-Köster E, Friedrich H. Parentage verification of South African Angora goats, using microsatellite markers. South African Journal of Animal Science. 2011;41:250-255

[32] Garritsen C, van Marle-Köster E, Snyman MA, Visser C. The impact of DNA parentage verification on breeding value estimation and sire ranking in South African Angora goats. Small Ruminant Research. 2015;124:30-37 
[33] Visser C, van Marle-Köster E, Bovenhuis H, Crooijmans RP. QTL for mohair traits in South African Angora goats. Small Ruminant Research. 2011;100:8-14

[34] Visser C, van Marle-Köster E, Snyman MA, Bovenhuis H, Crooijmans RP. Quantitative trait loci associated with pre-weaning growth in South African Angora goats. Small Ruminant Research. 2013;112:15-20

[35] Andrews M, Visser C, van Marle-Köster E. Identification of novel variants for KAP 1.1, KAP 8.1 and KAP 13.3 in South African goats. Small Ruminant Research. 2017;149:176-180

[36] Tosser-Klopp G, Bardou P, Bouchez O, Cabau C, Crooijmans R, Dong Y, DonnadieuTonon C, Eggen A, Heuven HC, Jamli S, Jiken AJ, Klopp C, Lawley CT, McEwan J, Martin P, Moreno CR, Mulsant P, Nabihoudine I, Pailhoux E, Palhière I, Rupp R, Sarry J, Sayre BL, Tircazes A, Wang J, Wang W, Zhang W, International Goat Genome Consortium. Design and characterization of a 52K SNP chip for goats. PLoS One. 2014;9:e86227

[37] Lashmar SF, Visser C, van Marle-Köster E. Validation of the 50k Illumina goat SNP chip in the South African Angora goat. South African Journal of Animal Science. 2015;45:56-59

[38] Lashmar SF, Visser C, van Marle-Köster E. SNP-based genetic diversity of South African commercial dairy and fiber goat breeds. Small Ruminant Research. 2016;136:65-71

[39] Visser C, Lashmar SF, van Marle-Köster E, Poli MA, Allain D. Genetic diversity and population structure in South African, French and Argentinian Angora goats from genomewide SNP data. PLoS One. 2016;11:e0154353

[40] Visser C, Hefer CA, van Marle-Köster E, Kotze A. Genetic variation of three commercial and three indigenous goat populations in South Africa. South African Journal of Animal Science. 2004;34:24-27

[41] Kotze A, Swart H, Grobler JP, Nemaangani A. A genetic profile of the Kalahari Red goat breed from Southern Africa. South African Journal of Animal Science. 2004;34:10-12

[42] Huson HJ, Sonstegard TS, Silverstein J, Woodward-Greene MJ, Masiga C, Muchadeyi F, Rees J, Sayre B, Elbetagy A, Rothschild M, Mujibi FD, Mwai O, Kemp S, Colli L, Ajmone-Marsan P, Crepaldi P, Abegaz S, Soelkner J, Van Tassel CP, AGIN. Genetic and phenotypic characterization of African goat populations to prioritize conservation and production efforts for small-holder farmers in Sub-Saharan Africa. In: Proceedings of the 10th World Congress of Genetics Applied to Livestock Production; August 2014; Vancouver, Canada. pp. 1-4

[43] Mdladla K. Population structure and breed relations of South African indigenous goat ecotypes using genome-wide SNP data. In: Plant and Animal Genome XXIII Conference; January 2015; San Diego, CA

[44] Mdladla K, Dzomba EF, Muchadeyi FC. P5039 A landscape genomic approach to unravel the genomic mechanism of adaptation in indigenous goats of South Africa. Journal of Animal Science. 2016;94(Supplement 4):134-135

[45] Mdladla K, Dzomba EF, Huson HJ, Muchadeyi FC. Population genomic structure and linkage disequilibrium analysis of South African goat breeds using genome-wide SNP data. Animal Genetics. 2016;47:471-482 
[46] Scheepers RC, van Marle-Köster E, Visser C. Genetic variation in the kappa-casein gene of South African goats. Small Ruminant Research. 2010;93:53-56

[47] Grobler R, Visser C, Chessa S, van Marle-Köster E. Genetic polymorphism of CSN1S2 in South African dairy goat populations. South African Journal of Animal Science. 2017;47:72-78

[48] Bosman L, van Marle-Köster E, Visser C. Genetic diversity of South African dairy goats for genetic management and improvement. Small Ruminant Research. 2015;123:224-231 